\title{
A Literature Review of Research Between Supply Chain Constraits Issues and Decree of The Government of Indonesia During Covid-19
}

\author{
Monica Dita Pravita Widya Putri *, Chaoyi Xu **, Larsey Naphtali Akwetteh ** \\ ${ }^{*}$ School of Economics and Management, Anhui University of Science and Technology, Huainan, P.R. China \\ ${ }^{* *}$ School of Economics and Management, Anhui University of Science and Technology, Huainan, P.R. China \\ **** School of Economics and Management, Anhui University of Science and Technology , Huainan, P.R. China
}

DOI: 10.29322/IJSRP.10.10.2020.p10606

http://dx.doi.org/10.29322/IJSRP.10.10.2020.p10606

\begin{abstract}
Purpose - The purpose of this study is to find out more about supply chain problems during the Covid-19 pandemic in Indonesia and how government decisions help solve supply chain problems, by forming several policies by adjusting the situation and conditions during the Covid-19 pandemic in Indonesia. Methodology - We use some literature both from Indonesia and from research abroad which are related and have a similar relationship with the problems that occur in Indonesia today relating to supply chain constraints. The literature is taken from several previous research journals, government regulations, and reviews of research conducted by previous researchers. Result and findings - lower interest rates, tax elimination, and direct assistance to business actors to provide assistance to ensure the smooth running of the supply chain and reduce spikes in costs and prices for necessities in the community. The leniency of regulations to facilitate supply chains to be able to distribute goods and services to various regions is not hampered even though Covid-19 is hitting Indonesia. Research implication - This study seeks to add to the still limited literature on supply chains during the Covid-19 pandemic in Indonesia. Also, this research can be used as a framework for educational institutions such as universities and government agencies to provide important references regarding supply chain management during the Covid19 pandemic, especially in Indonesia. Limitation - The study was carried out by analyzing some of the existing literature and more research is still needed regarding the efficiency and effectiveness of government policies on supply chain control and performance during the Covid-19 Pandemic in Indonesia, and the results are based on descriptive analysis only. Future research - Further studies can use research-based on quantitative analysis to measure the extent of supply chain constraints and the efficiency of the Indonesian government's decisions in overcoming supply chain problems in Indonesia during the Covid-19 pandemic.
\end{abstract}

Index Terms- Supply Chain Management, Logistics System, Covid-19 Pandemic, Indonesian Government Policy

\section{INTRODUCTION}

Since the Indonesian government confirmed that there were the first two positive cases of the Corona Virus (COVID-19) in Indonesia on March 2, 2020, the spread of COVID-19 has continued to increase by 207,203 infected cases as of Thursday, September 10, 2020. In a number of these cases, 147,510 patients were declared cured and 8,456 patients were declared dead (BNPB, 2020) and followed by the World Health Organization (WHO) decision to announce Covid-19 as a pandemic on March 11,2020 . On that date, the world's infected cases had reached 121,000 cases (Utomo, 2020). One month later, President Joko Widodo announced and declared Covid-19 a national disaster. This determination was based on the Presidential Decree (Keppres) of the Republic of Indonesia no. 12 of 2020 concerning the determination of the Non-Natural Disaster for the Spread of Corona Virus Disease 2019 (Covid-19) as a National disaster (Sekretariat Kabinet RI, 2020). To accelerate the handling of the Covid-19 pandemic, the Indonesian government has issued several strategies and preventive policies that are continuously being carried out to minimize the risk of the spread of the coronavirus (Djalante, et al., 2020). According to the Badan Siber dan Sandi Negara (National Cyber and Crypto Agency) (2020), the most important strategic stages related to company operational processes and supply chain security risk management to minimize the impact of COVID-19 on the business continuity process are the preparation and planning stages. Inadequate preparation causes instability in the existing supply chain. This is due to the existence of a government policy to impose Large-Scale Social Restrictions (PSBB) in almost all regions of Indonesia. PSBB not only inhibits the flow of people's movement but also hinders the movement of industry, distribution of goods, and the circulation of money (Baldwin \& Mauro, 2020). A significant decline has also occurred in the trend of growth in the number of freight trains on Indonesian freight trains during the pandemic. This is due to the disconnection of the supply chain which causes rail goods transportation activities to decline (Direktorat Jendral Perhubungan Darat, 2020). 


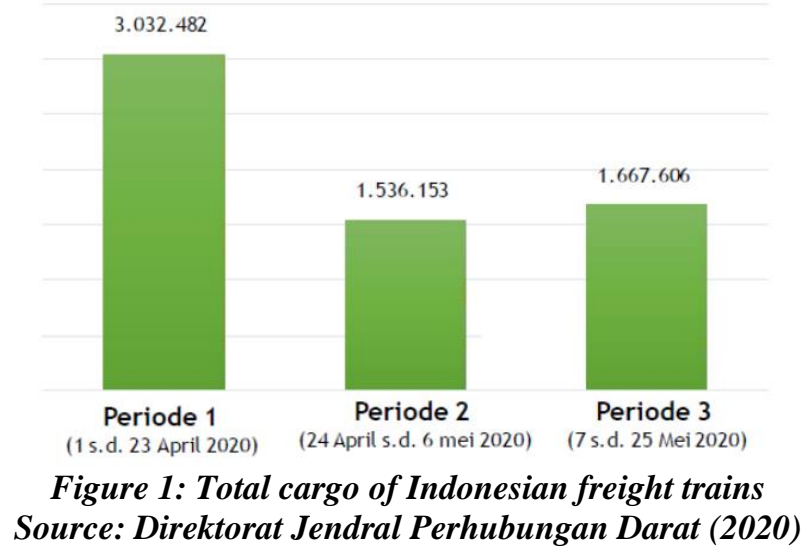

Further research is needed to understand the main barriers to supply chain management in Indonesia during Covid-19. Therefore, this study further aims to discuss trends, challenges, and perspectives on supply chain management systems in Indonesia during a pandemic. Based on this discussion, a solution was produced for the supply chain system in Indonesia, especially for the new normal Covid-19 pandemic.

\section{RESEARCH Motivation}

The supply chain that runs in the public sector in 2020 tends to slow down, followed by a policy of regional restrictions in various regions in Indonesia as a measure to prevent the spread of Covid-19 in Indonesia (Mas'udi \& Winanti, 2020). According to Permana (2020) states that the pandemic and the new normal provide opportunities for the people's economic sector to enter the supply chain, which so far has only been controlled by big players and no longer places it on the periphery of the economic system.

Problems in the supply chain not only hit Indonesia but also other countries such as China as the first country infected with Covid-19. At the start of the second quarter in April when factory workers returned to their routine, the supply chain in China was still not as smooth as before the outbreak period (Chin, et al., 2020). Several preventive steps taken by China to boost their economic growth rate by reducing the social insurance burden on individual companies, reducing investment in infrastructure, increasing consumption, maintaining liquidity and lowering borrowing costs, stabilizing jobs, and more stimulus policies are being developed (Kupferschmidt \& Cohen, 2020).

The Indonesian government has currently issued policies that focus on the community, such as direct social assistance, tax incentives, relaxation and restructuring of SME loans, expansion of SME financing, and business recovery and consolidation (SETKAB, 2020). This policy has been running positively in the community, marked by the distribution of Rakyar Business Credit (KUR) which has increased significantly as well as credit expansion by state-owned banks which is expected to help recover the pace of the economy and save the supply chain that was hampered at the beginning of the Covid-19 pandemic at the beginning of the year 2020 (Kementerian Koordinator Bidang Perekonomian Republik Indonesia, 2020). Additional subsidies for KUR that focus on SMEs are expected to provide fresh air for entrepreneurs to survive this pandemic.
Further research is needed to understand the main obstacles to the supply chain cycle in Indonesia during the Covid-19 pandemic. Therefore, this study aims to evaluate and identify barriers and risks to the supply chain in Indonesia during the Covid-19 pandemic to overcome supply chain interruptions in Indonesia during the Covid-19 pandemic.

\section{RESEARCH PROBLEM}

The number of closings of factories, shops, companies, and SMEs has an immediate impact on one another among business actors. This is supported by downstream factories that rely on the spare parts they produce by SMEs. Without the spare parts and good logistics required to load materials and deliver products, many factories can barely produce or have no place to store their products (Xinhau, 2020). The same thing also applies in Indonesia, where the process of the supply chain is hampered where there is a decrease not only in production but also in the logistics supply chain, according to a report from Aptrindo in Mayasari (2020), namely a decrease in demand of up to $60 \%$ due to limited transportation fleets. On the other hand, there is a surge in demand through e-commerce applications, which is the best choice for people to still be able to meet their needs.

The increase in demand from e-commerce has not made supply chain stability run smoothly during the Covid-19 pandemic in Indonesia. This is due to strict regional restrictions with the implementation of health protocols which make it difficult for the supply chain to meet community needs. Limited raw materials from suppliers is also another factor in supply chain inhibition. Reduction of labor due to reduced company income in carrying out the production process causes scarcity of the supply chain and demand that continues to explode from time to time. However, the amount of supply chain growth still tends to decline, which is a crucial issue that must be addressed to increase supply chain growth and economic stability in Indonesia ahead of the new normal Covid-19 period.

\section{LITERATURE OVERVIEW}

\section{Supply Chain}

Disruption of the supply chain can pose significant challenges and can affect the performance of an organization (Hendricks \& Singhal, 2003). The incidence of natural disasters such as the tsunami in Japan in 2011 to the financial crisis in 2008 has provided a concrete picture of how the interconnectedness and nature of the supply chain can amplify even the smallest disruption (Hendricks \& Singhal, 2003). So that various studies have emerged that try to explain the antecedents of robust supply chains, starting from the network level (Kim, et al., 2015) to the organizational level (Bode, et al., 2011).

The level of disruption to business networks during the Covid-19 pandemic has challenged much of the previous understanding of resilient supply chains. Recent research states that this crisis has caused a rapid decline in several business and economic indicators, including the flow of productivity to global GDP (Harris, 2020). Several business sectors have also been hit due to the policy of reducing working hours and this is followed by a $16.24 \%$ reduction in workforce (Baveja, et al., 2020) and 
exacerbated by the closure of workplaces. According to Araz et al. (2020) that the Covid-19 pandemic is the biggest disruption and has had the most severe impact on global supply chains in the past decade. Each pandemic and supply chain provides its own imitation model of global supply chain disruption and predicts the severity of the impact of the Covid-19 pandemic on supply chain performance in various aspects (Ivanov, 2020).

In short, the Covid-19 pandemic has placed unprecedented pressure on supply chains in Indonesia and globally in most business and product categories. Previous literature on supply chain forecasting and disruption has been able to provide an early picture of the indications of the factors that can cause it. So that the Indonesian government with all the preventive steps that have been taken can predict the demand that will explode in the initial phase of the Covid-19 pandemic so that it can provide early warning and can give more priority to important supply chains.

\section{LOGISTIC MANAGEMENT}

According to the definition issued by the council of Logistics Management in Szymonik (2012) where logistics management is part of supply chain management which is responsible for planning, implementing, and controlling forward and backward flow that is efficient, effective and as a storage of goods, services and related information between points. origin and point of consumption to be able to meet handling needs. Responding to the problem of the Covid-19 pandemic requires an update on the need to be able to review previous literature on supply chain and logistics management (Laan, et al., 2016) and disaster relief management (Gupta, et al., 2016), risk management and practices resilience in supply chains (Wieland \& Wallenburg, 2013) (Hohenstein, 2015) and to be able to better understand operations in epidemic control (Dasaklis, et al., 2012) (Hobbs, 2020).

The regional lockdown policies and large-scale restrictions (PSBB) that apply in various regions including Indonesia (Hirawan \& Verselita, 2020) have led to a dramatic increase in demand for consumer goods and a pattern that is difficult to predict (Joshi \& Rahman, 2015). To overcome this challenge, several entrepreneurs are working with government agencies, organizations, and business stakeholders to solve supply chain logistics problems in order to control the growing demand.

Supply chain constrait issues in emerging country

Supply chain constraints as well as stronger demand have recorded significant growth (Saptana, 2016). Several industries targeted at the supply side were forced to close their businesses, most of which were marginal companies (Baldwin \& Mauro, 2020). Resolutions are needed to be able to realize more productive changes to reduce the adverse impact of constraints on supply chain profitability (Simatupang, et al., 2004). There are two ways in which a supply chain constraint-based approach can help managers improve supply chains, namely by providing a reliable global performance measure that helps chain members measure progress on achieving total supply chain revenue and by focusing on remedial efforts that have a dramatic impact on the performance of the supply chain (Stefanovic, 2014).

Supply chain constraints and economic losses were followed by the economic decline of all business networks caused by shocks due to the Covid-19 pandemic (Shafi, et al., 2020). The impact of this supply chain constraint occurred as a result of regional lockdown policies and social restrictions in various regions in Indonesia in order to reduce the spread of the Covid-19 virus (Ozili $\&$ Arun, 2020). The production process experiences barriers to social lockdowns and restrictions in various regions due to insufficient product availability between companies and will cause obstacles to both production and control activities in the supply chain (Oxford Business Group, 2020). These conditions ultimately require adjustment of policy strategies related to supply chain settlement and adjustment during the Covid-19 pandemic so that supply chain stability is maintained.

\section{INDONESIA GOVERNMENT POLICIES REGULATING SUPPLY CHAINS}

During the Covid-19 pandemic, there was a decline in logistics performance which affected the fulfillment of supply chains in Indonesia. In 2019 the logistics business grew 15\%, while in 2020 during the 5 months of the Covid-19 pandemic in Indonesia, it experienced a drastic decline and lost and fell to $60 \%$, while the business utility was only around 40\% (APTRINDO, 2020). Until August 2020 only $40 \%$ of the total supply chain distribution capacity was working, this was due to the social lockdown and restriction policies set by the government since the beginning of the Covid-19 pandemic in Indonesia (Patunru, et al., 2020). Several strategic steps have been taken by the government to stabilize the supply chain and logistics distribution to the public in full, starting from relaxing the repayment of principal loans for freight forwarding companies for 12 months, either through investment loans through banks or non-banks (leasing), to reducing loan interest rates by $50 \%$, income tax Article $21(\mathrm{Pph}$ Article 21) is eliminated for 12 months, relaxation of income tax article 23 (Pph Article 23), relaxation of income tax article 25 (Pph Article 25), providing direct cash assistance to industry players to support supply chains, and certainty of business permits and operating permits for transportation vehicles (APTRINDO, 2020).

\section{LITERATURE SUMMARY}

There are 10 strategies to improve and overcome supply chain constraints according to Simatupang et al. (2004) namely utilizing an ERP system that has automatic features and supply chain management functionality, using standardization of ERP, increasing supply chain transparency, gaining data insights through ERP, real-time inventory management, monitoring vendor performance, level of awareness of expenses, increasing return management, just-in-time model and streamlined accounting. However, with the conceptual integration of the previous theory and the conceptual framework of the theory above (Simatupang, et al., 2004) (Saldanha, et al., 2015) (Simatupang, et al., 2004) (Larsen \& Bagchi, 2002) (Sanders \& Premus, 2005), this paper has identified four main strategies that will be used in analyzing overcoming supply chain constraints in Indonesia. The four main strategies are based on increasing supply chain transparency, real-time inventory management, monitoring vendor work, and level of awareness of expenses. According to (Yuan, 2011) defines the constraints of the supply chain involving internal and external processes: therefore the four strategies above 
will be classified into internal and external factors based on the source of their impact. Internal factors are caused from within the company, while external factors are influenced from outside the company.

Internal factors consist of increasing supply chain transparency and the level of awareness regarding expenditures. Increasing supply chain transparency in the business sector will be the main measure of the success and sustainability of the supply chain during the Covid-19 Pandemic, especially in Indonesia. This section will study the attitudes, perceptions, and knowledge of business owners about supply chain transparency that they have been implementing so far because it is very important to be able to find out more details about supply chain handling and further policy decisions from business owners. Expenditure monitoring is also an important aspect of the sustainability of the supply chain, especially during the Covid-19 pandemic, because there is limited space for the continuity of the supply chain, causing both business owners and the community and government to work together to provide the best gap for the continuity of supply chains in Indonesia.

On the other hand, external factors include real-time inventory management and monitoring of vendor performance. Some of the current problems during the Covid-19 pandemic are the disconnection of the supply chain as a result of regional lockdowns and social restrictions imposed in several regions which makes it difficult to get the main raw materials for production. Not only raw material difficulties but lack of supervision on vendor performance has led to a decline in the quality of the existing supply chain. The granting of limited permits and access for business actors to provide flexibility in the distribution of their supply chains by the Indonesian government has not yet been able to solve this problem. This is due to the reduction in the number of employees due to the lack of income due to lockdowns and restrictions on areas in various areas that narrow the space for production from existing business patterns. More support from the government is needed and a little leniency on public space and safety guarantees for workers. The government has provided assistance in the form of tax concessions and direct cash assistance to businesses to continue their business, which more or less has helped sustain the supply chain to meet needs during the Covid-19 pandemic in Indonesia. Therefore, it is necessary to have a government perception regarding the extent to which the supply chain has been running and to acknowledge government support for supply chain constraints in Indonesia. In addition, testing the readiness of the new work structure of the supply chain is also very important to find out how effective the new policies that have taken place during the Covid-19 pandemic in Indonesia are.

Table 1. Literature Summary of Supply Chain Constraints during the Covid-19 Pandemic and Indonesian Government Policies

\begin{tabular}{lll}
\hline Key Element & Description & Source \\
\hline Organizational & Knowledge $\quad$ of & (Saldanha, et al., \\
& overcoming supply & 2015), \\
& chain constraints. & (Simatupang, et \\
& & al., $\quad$ 2004), \\
& & (Larsen
\end{tabular}

Organizational

culture in managing

the supply chain.

Bagchi, 2002),

(Sanders \&

Premus, 2005), (APTRINDO, 2020)

\begin{tabular}{|c|c|c|}
\hline $\begin{array}{l}\text { Market } \\
\text { Industry }\end{array}$ & $\begin{array}{l}\text { Adoption of supply } \\
\text { chain constraint } \\
\text { handling. }\end{array}$ & $\begin{array}{l}\text { (Nowakowska \& } \\
\text { Moroz, 2013), } \\
(\text { Lockamy } \& \\
\text { Draman, 1998), } \\
\text { (Larsen } \\
\text { Bagchi, 2002) }\end{array}$ \\
\hline External Support & $\begin{array}{l}\text { The policies of each } \\
\text { industry to } \\
\text { overcome supply } \\
\text { chain constraints. } \\
\text { Industry awareness } \\
\text { in saving business } \\
\text { and industrial } \\
\text { turnover. }\end{array}$ & $\begin{array}{l}\text { (Nguegan \& } \\
\text { Mafini, 2017), } \\
\text { (Simatupang, et } \\
\text { al., } 2004), \\
\text { (Sabet, et al., } \\
\text { 2017), } \\
\text { (APTRINDO, } \\
\text { 2020) }\end{array}$ \\
\hline $\begin{array}{l}\text { Government } \\
\text { policy }\end{array}$ & $\begin{array}{l}\text { Government } \\
\text { initiatives in } \\
\text { implementing } \\
\text { supply chain } \\
\text { policies during the } \\
\text { Covid-19 pandemic. } \\
\text { The availability of a } \\
\text { research center to } \\
\text { support the handling } \\
\text { of supply chain } \\
\text { constraints during } \\
\text { the Covid-19 } \\
\text { pandemic. } \\
\text { Regulations and } \\
\text { policies for supply } \\
\text { chain handling. }\end{array}$ & $\begin{array}{l}\text { (OCHA \& RCO, } \\
2020), \quad \text { (OECD, } \\
2020), \quad \text { (Goller, } \\
2020), \\
\text { (APTRINDO, } \\
2020)\end{array}$ \\
\hline
\end{tabular}

\section{RESEARCH CONTRIBUTION}

The findings of this paper not only identify constraints and constraints on supply chain distribution during the Covid-19 pandemic that hinder the circulation and distribution of goods and services but also indicate important steps that other countries can replicate in taking policies to remove bottlenecks in supply chains. in Indonesia. Thus, the conceptual framework and findings of this paper may be applied in other developing countries that have similar problems with Indonesia today. The paper also identifies steps the Indonesian government has taken to prevent bottlenecks in Indonesia's supply chain. Therefore, business actors and businesses can focus on returning to producing goods and services in order to restore economic activity in Indonesia. In addition, full support from the government and the policies that have been issued are very important in regulating the regulation and circulation of goods in the supply chain in Indonesia during the Covid-19 pandemic and can be used as guidelines and references to support and improve the supply chain that was hampered at the beginning of the Covid-19 pandemic. 


\section{REFERENCES}

[1] APTRINDO, 2020. Tantangan Distribusi Logistik pada Masa Pandemi Covid-19. [Online]

[2] Available https://aptrindo.or.id/assets/uploads/Tantangan_Distribusi_Logistik_pada Masa_Pandemi_Covid19.pdf [Accessed 12 September 2020].

[3] Araz, O., Choi, T. M., Olson, D. \& Salman, F. S., 2020. Data analytics for operational risk management.. Decision Sciences.

[4] Baldwin, R. \& Mauro, B. W. d., 2020. Economics in the Time of COVID-19. London, UK: CEPR Press.

[5] Baldwin, R. \& Mauro, B. W. d., 2020. Economics in the Time of COVID-19. [Online]

[6] Available at: https://cepr.org/sites/default/files/news/COVID-19.pdf [Accessed 12 September 2020].

[7] Baveja, A., Kapoor, A. \& Melamed, B., 2020. Stopping COVID-19: A pandemic-management service value chain approach. SSRN Scholarly Paper No. ID 3555280

[8] BNPB, 2020. Satuan Tugas Penanganan COVID-19. [Online] Available at: https://covid19.go.id/ [Accessed 11 September 2020].

[9] Bode, C., Wagner, S. M., Petersen, K. J. \& Ellram, L. M., 2011. Understanding responses to supply chain disruptions: Insights from information processing and resource dependence perspectives.. Academy of Management Journal, 54(4), p. 833-856.

[10] Brustbauer, J., 2016. Enterprise risk management in SMEs: Towards a structural model. International Small Business Journal, 34(1), pp. 70-85.

[11] BSSN, 2020. Panduan Keamanan Siber Manajemen Risiko Keamanan di Tengah Pandemi Covid-19. Jakarta.

[12] Chin, H., Kong, W., He, W. \& Cheung, D., 2020. COVID-19 impacts on China's economy and global supply chains: Recent developments and updated assessments. Fung Busines Intelligence, pp. 1-26.

[13] Darat, D. J. P., 2020. Tantangan Industri Logistik Dalam Masa Pandemi COVID-19. Jakarta, Webinar Transportasi dan Logistik Saat dan Pasca Pandemi Covid-19 di Indonesia.

[14] Darmawi, H., 2016. Manajemen Risiko. Jakarta: Bumi Aksara.

[15] Dasaklis, T. K., Costas, P. P. \& Nikolaos, P. R., 2012. Epidemics control and logistics operations: A review. International Journal of Production Economics, Volume 139, pp. 393-410.

[16] Djalante, R. et al., 2020. Review and analysis of current responses to COVID19 in Indonesia: Period of January to March 2020. Progress in Disaster Science, Volume 6.

[17] Goller, L., 2020. COVID-19 Impact: The State -and Future -of the Supply Chain. [Online]

[18] Available at: https://www.rangeme.com/blog/covid19-impact-the-state-andfuture-of-the-supply-chain/ [Accessed 12 September 2020].

[19] Gupta, S., Martin, K. S., Reza, Z. F. \& Niki, M., 2016. isaster management from a POM perspective: Mapping a new domain. Production and Operations Management, 25(10), pp. 1611-1637.

[20] Harris, R., 2020. Covid-19 and productivity in the UK. Durham University Business School.

[21] Hendricks, K. B. \& Singhal, V. R., 2003. The effect of supply chain glitches on shareholder wealth. Journal of Operations Management, 21(5), pp. 501522 .

[22] Hirawan, F. B. \& Verselita, A. A., 2020. Kebijakan Pangan di Masa Pandemi COVID-19. CSIS Commentaries, pp. 1-7.

[23] Hobbs, J. E., 2020. Food supply chains during the COVID-19 pandemic. [Online]

[24] Available at: https://doi.org/10.1111/cjag.12237

[25] Hohenstein, N., 2015. Research on the phenomenon of supply chain resilience A systematic review and paths for further investigation. International Journal of Physical Distribution \& Logistics Management, 45(1), pp. 90-117.

[26] Ivanov, D., 2020. Predicting the impacts of epidemic outbreaks on global supply chains: A simulation-based analysis on the coronavirus outbreak (COVID-19/SARS-CoV-2) case. Transportation Research Part E: Logistics and Transportation Review, Volume 136.

[27] Joshi, Y. \& Rahman, Z., 2015. Factors Affecting Green Purchase Behaviour and Future Research Directions. International Strategic Management Review, 3(1-2), pp. 128-143.
[28] Kim, Y., Chen, Y. S. \& Linderman, K., 2015. Supply network disruption and resilience: A network structural perspective.. Journal of Operations Management, Volume 33, p. 43-59.

[29] Kupferschmidt, K. \& Cohen, J., 2020. China's aggressive measures have slowed the coronavirus. They may not work in other countries. [Online] Available at: https://www.sciencemag.org/news/2020/03/china-saggressive-measures-have-slowed-coronavirus-they-may-not-work-othercountries [Accessed 11 September 2020].

[30] Laan, E., Dalen, J., Rohrmoser, M. \& Simpson, R., 2016. Demand forecasting and order planning for humanitarian logistics: An empirical assessment. Journal of Operations Management, 45(1), pp. 114-122.

[31] Larsen, D. T. S. \& Bagchi, D. P., 2002. Challenges of Integration in Supply Chain Networks: An European Case Study. ACES Working Paper.

[32] Lockamy, A. \& Draman, R. H., 1998. A Constraint-Based Methodology for Effective Supply Chain Management. The International Federation for Information Processing, Volume 2, pp. DOI: 10.1007/978-0-387-35321-0.

[33] Mas'udi, W. \& Winanti, P. S., 2020. New Normal, Perubahan Sosial Ekonom dan Politik Akibat COVID-19. Jogjakarta: Gajahmada University Press.

[34] Mayasari, S., 2020. Ada Corona, Permintaan Jasa Truk Anjlok Hingga 60\%. [Online]

[35] Available at: https://industri.kontan.co.id/news/adacorona-permintaan-jasatruk-anjlok-hingga60 [Accessed 11 September 2020].

[36] Mentri Koordinator Bidang Perekonomian Republik Indonesia, 2020. Peraturan Menteri Koordinator Bidang Perekonomian Republik Indonesia No. 8 tahun 2020, Jakarta: Mentri Koordinator Bidang Perekonomian Republik Indonesia.

[37] Misbah, M., 2017. Asesmen Maturitas Manajemen Risiko Perusahaan pada Kontraktor Kecil dan Menengah. Jurnal Teknik Mesin Mercu Buana, 6(2), pp. 147-154.

[38] Nguegan, C. A. N. \& Mafini, C., 2017. Supply chain management problems in the food processing industry: Implications for business performance. Acta Commercii, 17(1), p. DOI: 10.4102/ac.v17i1.485.

[39] Nowakowska, G. J. \& Moroz, E., 2013. Theory of Constraits as an Effective Tool For Supply Chain Management. Advance Logistic Management.

[40] OCHA \& RCO, 2020. Indonesia Multi-Sectoral Response Plan to Covid-19. [Online]

[41] Available at: https://reliefweb.int/sites/reliefweb.int/files/resources/covid19msrp-v7.pdf [Accessed 11 September 2020].

[42] OECD, 2020. Food Supply Chains and COVID-19: Impacts and Policy Lessons. [Online]

[43] Available at: https://read.oecd-ilibrary.org/view/?ref=134_134305ybqvdf0kg9\&title=Food-Supply-Chains-and-COVID-19-Impacts-andpolicy-lessons [Accessed 12 September 2020].

[44] Oxford Business Group, 2020. The impact of Covid-19 on global supply chains. [Online]

[45] Available at: https://oxfordbusinessgroup.com/news/impact-covid-19global-supply-chains [Accessed 12 September 2020].

[46] Ozili, P. K. \& Arun, T., 2020. Spillover of COVID-19: impact on the Global Economy. SSRN Electronic Journal, Volume 10.2139/ssrn.3562570, pp. 127.

[47] Patunru, A., Octania, G. \& Audrine, P., 2020. [Ringkasan Kebijakan] Penanganan Gangguan Rantai Pasok Pangan di Masa Pembatasan Sosial. [Online] Available at: https://id.cips-indonesia.org/post/ringkasankebijakan-penanganan-gangguan-rantai-pasok-pangan-di-masa-pembatasansosial [Accessed 12 September 2020].

[48] Permana, P., Farhana, N. A. \& Miantantri, K., 2020. Adaptasi Mobilitas Masyarakat Kota Dalam Masa Pandemi: Peluang Transisi Menuju Transportasi Berkelanjutan?. Dalam: New Normal, Perubahan Sosial Ekonomi dan Politik Akibat COVID-19. Jogjakarta: Gajah Mada University Press.

[49] Qintharah, Y. N., 2019. Perancangan Penerapan Manajemen Risiko. Jurnal Riset Akuntansi Dan Komputerisasi Akuntansi, 10(1), pp. 67-86.

[50] Sabet, E., Yazdani, N. \& Leeuw, S. D., 2017. Supply chain integration strategies in fast evolving industries. The International Journal of Logistics Management, 28(1)

[51] Saldanha, J. P., Mello, J. E., Knemeyer, A. M. \& S, V. T. A., 2015. Coping Strategies for Overcoming Constrained Supply Chain Technology: An Exploratory Study. Transportation Journal, 54(2), p. 10.5325/transportationj.54.3.0368. 
[52] Sanders, N. \& Premus, R., 2005. Modeling the Relationship between Firm IT Capability, Collaboration, and Performance. Journal of Business Logistics, 26(1), pp. 1-23.

[53] Saptana, R. D. Y., 2016. Supply Chain Management Concept Implementation in Poultry Products. Agro Economist Research Forum, 34(2), pp. 143-161.

[54] Sekretariat Kabinet Republik Indonesia, 2020. Presiden Tetapkan Bencana Nonalam Penyebaran Covid-19 sebagai Bencana Nasional. [Online] Available at: https://setkab.go.id/presiden-tetapkanbencana-nonalampenyebaran-covid-19- sebagai-bencana-nasional/ [Accessed 11 September 2020].

[55] Sekretariat Kabinet RI, 2020. Kebijakan Pemulihan Ekonomi di Masa Pandemi Berhasil Tingkatkan Penyaluran KUR Bulan Juni. [Online] Available at: https://setkab.go.id/kebijakan-pemulihan-ekonomi-di-masapandemi-berhasil-tingkatkan-penyaluran-kur-bulan-juni/ [Accessed 11 September 2020].

[56] Shafi, M., Liu, J. \& Ren, W., 2020. Impact of COVID-19 pandemic on micro, small, and medium-sized Enterprises operating in Pakistan. Research in Globalization, Volume 2, p. https://doi.org/10.1016/j.resglo.2020.100018.

[57] Simatupang, T. M., Mright, R. G. \& Sridharaw, R., 2004. Applying the theory of constraints to supply chain collaboration. Supply Chain Management: An International journal, 9(1), pp. 57-70.

[58] Stefanovic, N., 2014. Proactive Supply Chain Performance Management with Predictive Analytics. The Scientific World Journal.

[59] Szymonik, A., 2012. Logistics and Supply Chain Management. Łódź, Poland: Lodz University of Technology.

[60] Utomo, A. P., 2020. WHO Umumkan Virus Corona sebagai Pandemi Global. [Online] Available at: https://www.msn.com/idid/berita/dunia/who-
umumkan-virus-coronasebagai-pandemi-global/ar-BB113bKq [Accessed 11 September 2020].

[61] Wieland, A. \& Wallenburg, C., 2013. The influence of relational competencies on supply chain resilience: a relational view. International Journal of Physical Distribution \& Logistics Management, 43(4), pp. 300320.

[62] Xinhau, N. A., 2020. Analysis of Regional Policies on Businesses Reopening Support, China Economic Information Service. Economic Analysis Report, 1048(2).

[63] Yuan, J. M., 2011. Analysis of knowledge management barriers in enterprise supply chain and its countermeasures. IEEE, p. DOI 10.1109/CSSS.2011.5975037

\section{AUTHORS}

First Author - Monica Dita Pravita Widya Putri School of Economics and Management, Anhui University of Science and Technology , Huainan, P.R. China, monicadpwp@gmail.com

Second Author - Chaoyi Xu, School of Economics and Management, Anhui University of Science and Technology, Huainan, P.R. China, 3910379@qq.com

Third Author - Larsey Naphtali Akwetteh, School of Economics and Management, Anhui University of Science and Technology , Huainan, P.R. China, nlarsey.nl@gmail.com 